ELORE (ISSN 1456-3010), vol. 19 - 2/2012.

Julkaisija: Suomen Kansantietouden Tutkijain Seura ry.

[http://www.elore.fi/arkisto/2_12/apo.pdf]

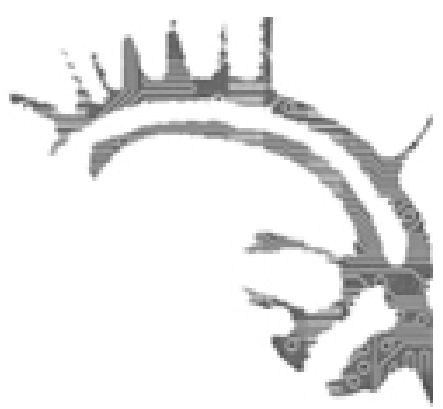

\title{
EMINENTIA-LIITE
}

\section{SATUGENRE KIRJALLISUUDENTUTKIMUKSEN JA FOLKLORISTIIKAN RIITAMAANA}

\author{
$\underline{\text { Satu Apo }}$
}

Esitelmä Suomen Kansantietouden Tutkijain Seuran VI Kevätkoulun Eminentialuennot-seminaarissa 15.5.2012 Tieteiden talossa Helsingissä.

Satujen historian tutkimuksessa on parhaillaan tapahtumassa paradigman vaihto. Polttopisteessä ovat nimenomaan ihmesadut (Zaubermärchen, contes des fées, fairy tales = tales of magic) eli folkloren tunnetuin ja suosituin laji. Tutkijat ovat joutuneet aina Antti Aarneen (1867-1925) päivistä alkaen ottamaan kantaa siihen, että monet "kansan" suullisesta kerronnasta saadut tallenteet ovat näyttäytyneet myös Euroopan kirjallisuudessa 1500-luvulta lähtien. Perinteinen käsitys on ollut se, että varhaiset kirjalliset ihmesadut polveutuvat suullisista kansansaduista. Aikamme ahkerin saduntutkija, Jack Zipes, kirjoitti vuonna 1979 asiasta seuraavasti: "Kertomus, josta me tavallisesti käytämme nimitystä fairy tale, on monissa tapauksissa kansansatu, joka pohjautuu primitiivisten kansojen kokemuksiin ja fantasiaan, ja se on ollut osa näiden kansojen suullista traditiota." Tälle satutraditiolle on haluttu antaa huikeat juuret, joita Zipes kuvaa seuraavasti: "Historialliset, sosiologiset ja antropologiset tutkimukset ovat osoittaneet, että kansansadun synty palautuu aina megaliittiselle kaudelle saakka, ja kansanihmiset ovat levittäneet ja muunnelleet näitä kertomuksia." (Zipes 1979, ix.) Megaliittinen kausi vastaa pronssikautta, joka Euroopassa alkoi noin 2000 eaa ja päättyi noin 500 eaa.

Zipesin määrittelylläkin on pitkä historia; se palautuu romantiikan aikaan ja Jacob ja Wilhelm Grimmiin. Veljesten mukaan ne ihmesadut, jotka esiintyvät sekä kirjallisessa 
että suullisessa traditiossa, ovat kehkeytyneet "kansan", etenkin talonpoikien vaalimassa suullisessa perinteessä, jonka juuret ulottuvat esihistoriaan ja muinaisgermaaniseen mytologiaan. Kansansadut ovat siis aina primaareja ja niiden kaunokirjalliset vastineet sekundaareja. Sama credo kaikui suomalaisen koulukunnan metodioppaissa - ja niillä Jouko Hautalan pitämillä luennoilla, joita kuuntelin fuksina syksyllä 1967. Hautala suhtautui penseästi kirjallisuudentutkimukseen ja varoitti folkloristeja ottamasta sitä sivuaineekseen.

Nyt kirjallisuudentutkijat ovat haastaneet folkloristiikan väittämällä, että historiallisesti varsin myöhäinen ilmiö, monimuotoiset painotuotteet (kirjat, arkit, almanakat, lehdistö), ovat vaikuttaneet eurooppalaisiin kansansatuihin paljon voimakkaammin kuin on tiedetty tai haluttu uskoa. Muinaisuuteen kurkottavaa Grimmien, Aarnen ja Zipesin edustamaa pardigmaa on ravisteltu kahdelta suunnalta. Näistä ensimmäinen on uusin tutkimus, joka kohdistuu Euroopan vanhaan satukirjallisuuteen - tätä julkaistiin 1550-luvulta 1700-luvun loppuun. Toinen tutkimuksen alue, joka on nostanut esiin uusia ja kiusallisia kysymyksiä, on Grimmin satujen lähteiden analyysi. Mitä tarkemmin veljesten toimitustyötä on selvitetty, sitä vähäisemmäksi kansankertojien ja suullisen tradition rooli on kutistunut. Vahvasti kirjallinen Kinder-und Hausmärchen (1812-1822, 1857) ehti ennen kansansatujen keruuta vaikuttaa suulliseen kerrontaan sekä saksankielisillä alueilla että Pohjoismaissa. Ranskalaiset ja englantilaiset käännökset levittivät Grimmin sadut ympäri Eurooppaa sekä moniin siirtomaihin.

\section{HARVAPIIRTEINEN VARHAISHISTORIA}

Ihmiskunnan vanhimmat sadut on todella tavoitettu pronssikaudelta, Egyptin keski- ja uuden valtakunnan ajalta (1994 eaa-1000 eaa). Tutkijat olettavat, että nuoret kirjurioppilaat ovat näiden papyrustekstien avulla harjoitelleet hieroglyfikirjoitusta. (Grandet 1998, I-IV.) Tietyissä saduissa näkyy meille tuttuja aihelmia, ehkä selvimmin Kahdessa veljeksessä (= Anup ja Bata). Maata viljelevistä veljeksistä nuorempi, Bata, on vainottu sankari. Häntä yrittää saada hengiltä ensin hänen veljensä Anup ja sitten farao, joka on ryöstänyt hänen jumalallisen ihanan vaimonsa. Henkensä pitimiksi Bata joutuu muuntautumaan moneen muotoon, ensin häräksi, sitten kahdeksi puuksi ja lopulta kaadetun puun lastuksi. Lastu osuu Batan uskottomaan vaimoon ja saattaa hänet raskaaksi. Kun aika on täysi, vaimo synnyttää Batan uudestaan. Kuoleman voittanut sankari nousee faraon valtaistuimelle. (Grandet 1998, 97-110.)

Muodonmuutoskamppailu on tuttu sadusta Noidan oppipoika (ATU 325). ${ }^{1}$ Suomalaisten kansansatujen sankarit muuntautuvat ensin hevoseksi, sitten linnuksi, haueksi, sormukseksi, siemeniksi, ketuksi ja lopulta omenapuuksi. (Rausmaa 1988, 82-90.)

Todistaako Kaksi veljestä, että ihmesatuja kerrottiin jo muinaisessa Egyptissä? Tutut aihelmat - esimerkiksi alhaissyntyisen sankarin nousu koko valtakunnan hallitsijaksi muodostavat vain pienen osan kertomuksen juonesta. Muu toiminta sijoittuu maailmaan, jota hallitsevat oudot jumalat ja luonnonvoimat. Anup-veljen katsotaan edustavan Anubista ja Batan härkäjumalaa. Henkilöhahmojen ja tapahtumien mytologiset merkitykset 
eivät avaudu eurooppalaisiin satuihin tottuneelle lukijalle. Egyptiläisiä satuja on myös säilynyt niin vähän, että niiden lajeja on vaikea määritellä.

Antiikin kreikkalainen ja roomalainen kirjallisuus sisälsi runsaasti fantasiaa Odysseuksen seikkailuista Ovidiuksen Metamorfooseihin. Jälkimmäisen runoissa kuvataan ihmisten ja nymfien muuttumista linnuiksi ja kasveiksi. Uuden ajan satuihin rinnastuu selvimmin Lucius Apuleiuksen (n. 125-180 jaa) kirjoittama latinankielinen Cupido ja Psyche. ${ }^{2}$ Kertomus alkaa tutulla "olipa kerran" formulalla ${ }^{3}$, ja se vilisee tuttuja satuaihelmia ja -episodeja. Kuninkaantytär saa itselleen näkymättömän, käärmeeksi väitetyn puolison ja lumotun linnan. Hän menettää molemmat seurauksena kateellisten sisarien juonittelusta. Sisukas Psyche selviytyy monista koettelemuksista sekä puolisonsa että ihmeellisten auttajien (muurahaisten, kaislan, puhuvan tornin) avulla. Kertomuksen lopussa Psyche saa Cupidonsa ja kohoaa Olympoon jumalien joukkoon. Yhtä "satumaisia" kertomuksia kuin Apuleiuksen fabula ei ole säilynyt nykypäiviin asti. Tästä syystä ihmesadut eivät erotu omaksi genrekseen antiikin kirjallisuudessa. (Vrt. Apo 2011, 89-90.)

Myös keskiajan kirjallisuus tulvii fantasiaa: germaanista ja anglosaksista mytologiaa lohikäärmeineen, jättiläisineen ja kääpiöineen (Beowulf, Edda), eläineepoksia, runo- ja proosamuotoisia romansseja ihmeellisine tapahtumineen ja toimijoineen (magiaa, haltiattaria, puhuvia lintuja). (Delarue 1957, 13-15.) Ihmesatuja muistuttavat itsenäiset kertomukset ovat edelleenkin harvinaisuuksia. Esimerkiksi Ruususen täyteläisin versio on vain laajan romanssin yksi episodi. ${ }^{4}$ Apuleiuksen romaanin päähenkilö, vahingossa aasiksi loihdittu nuorukainen, on saattanut antaa innoituksen keskiaikaiseen Asinarius -runokertomukseen. Tässä kuninkaanpoika syntyy aasina; lumouksen purkaa vasta avioituminen hyväluontoisen prinsessan kanssa. (Rölleke 1998, 170-183.)

Länsimaisen periodijaottelun mukaan myös Tubkimon ensimmäinen tunnettu versio kuuluu keskiaikaan. Kyseessä on kuitenkin näyte Kiinan klassisesta kirjallisuudesta 800-luvulla. Sadun kirjoittaja Tuang Ch'eng-shih (k. 863) kertoo sen olevan peräisin silloisen Etelä-Kiinan (nykyisen Vietnamin pohjoisosan) suullisesta traditiosta. (Ting 1974, 8; Apo 2011, 90-91.)

Kirjallisuuden lajeja alettiin Euroopassa määritellä tarkemmin vasta renessanssin humanistien toimesta. Lajien erottelun kriteerit ja kutakin lajia koskevat konventiot muodostivat tärkeän osan 1500-1600-lukujen poetiikasta. Tässä pelissä eivät ihmesadut pärjänneet. Ne oli jo antiikin aikana passitettu sanataiteen alimpaan kastiin, imettäjien ja lastenhoitajien viljelemiksi joutavuuksiksi. Oppineet miehet halveksivat vielä 1700 -luvulla fantasiakertomuksia, joita lapset ja typerä rahvas kuuntelivat iltojensa iloksi, ja joita esittivät myös naiset, vieläpä vanhat akat. (Moser-Rath 1977, 463-464.)

Kannattaakin muistaa, että kertomuslaji, jota nimitämme ihmesaduksi, on saanut tieteellisen märitelmänsä hyvin myöhään, vasta 1900-luvun alussa. Tällöin Aarne luokitteli ja luetteloi Zaubermächen -juonet varustaen ne tyyppinumeroilla 300-725. (Aarne 1910 /1959, 11-33). Lajin kriteereitä on pitkä rivi: ihminen päähenkilönä, fantasiapitoisuus, juoni sisältää useita tapahtumia ja toimijoita, onnellinen loppu. Myös ihmesadun pääfunktiota, ajanvietettä, on käytetty genreä määrittävänä muuttujana. Folkloristit muistuttavat, että satuihin ei ole uskottu ainakaan niiden ilmisisällön tasolla. Prototyyppinen sankarisatu on Lohikäärmeen tappaja (ATU 300); feminiinisistä 
Satu Apo: Satugenre kirjallisuudentutkimuksen ja folkloristiikan riitamaana

saduista tunnetuin on Tubkimo (ATU 510); lapsisankareista kertoo Lapset ja hirviö (Hannu ja Kerttu, ATU 327).

\section{GUTENBERG MUUTTI FOLKLOREN VIESTINTÄYMPÄRISTÖN}

Antiikin ja keskiajan kaunokirjallisuus eli käsikirjoituksina. Nämä levisivät käsintehtyinä kopioina, joita valmistettiin kristillisenä aikana luostarien kirjoituspajoissa (scriptorium). Työ oli aikaa vievää ja kallista. Luettavat tekstit olivat herrojen herkkua aina 1500-luvulle saakka. (Vrt. Heikkilä 2010, 26-33; Laine 2012, 53, 60.)

Johann Gensfleisch-Gutenbergin keksintö muutti kirjoitusten monistamisen nopeaksi ja halvaksi 1400-luvun lopusta lähtien. Seuraavalla vuosisadalla painolaatat ja -koneet alkoivat muuttaa kansankin kulttuuria Euroopan läntisissä maissa. Lukutaito lisääntyi reformaation ja sen vastareaktion siivittämänä. Rahvaan lukuharrastus suunnattiin aluksi uskonnolliseen kirjallisuuteen. (Laine 2012.) Huokea ajanviete astui kuitenkin areenalle ennen pitkää, Ranskassa jo 1500-luvulla. (Delarue 1957, 18.)

Koska painetut ja sidotut kirjat olivat edelleenkin suhteellisen kalliita, viihteelliset kertomukset levisivät yhteiskunnan alempien luokkien keskuuteen kirjasina ja arkkeina. Nämä painettiin huonolle paperille ja jätettiin sitomatta. Tällaista kirjallisuutta voitiin ostaa markkinoilta tai kierteleviltä kaupustelijoilta parilla kolikolla. Koska tekijänoikeuksia ei tunnettu, kustantajat etsivät rahvaalle sopivia tekstejä aiemmin julkaistuista kirjoista, tavallisimmin kertomuskokoelmista. Uusi lukemiskulttuuri poikkesi omastamme: sitä hallitsi ääneen lukeminen ja kuultujen tekstien edelleen kertominen suullisen viestinnän keinoin.

Ensimmäinen ihmesatuja sisältävä kertomuskokoelma julkaistiin Venetsiassa 1550-luvulla. Kyseessä oli Giovan Francesco Straparolan (1480-n. 1557) teos Piacevoli notti (Miellytttävät yöt). Kirjailijan elämästä ei tiedetä käytännöllisesti katsoen mitään. Kokoelman tunnetuimmat sadut ovat Costantino Fortunato (Saapasjalkakissa, ATU 545), Pietro Pazzo (Laiska poika, ATU 675) ja Fortunatus (Ihmeelliset hedelmät, ATU 566). Vasta Straparolan kokoelma liitti sadut eurooppalaisen kirjallisuuden lajivalikkoon. (Rubini 2007, 1360-1361, 1363.)

\section{BOTTIGHEIMERIN TEESIT}

Yleisen kirjallisuuden professori ja Grimmin satujen tutkija Ruth B. Bottigheimer kysyi kahdessa teoksessaan (Fairy Godfather 2002; Fairy Tales: A New History 2009), mistä Straparola oli saanut satunsa. Oliko hän kuullut ne kansankertojilta, joiden suullinen ohjelmisto periytyi keskiajalta? Toinen mahdollinen lähteistö oli Straparolan tuntema kirjallisuus. Kolmas vaihtoehto oli kirjailijan oma sepitystyö.

Bottigheimerin vastaukset järkyttivät folkloristeja. Ne eivät koskeneet vain Miellyttäviä öitä vaan tiivistyivät myös reippaiksi yleistyksiksi. Merkittävä ellei suurin osa eurooppalaisista ihmesaduista (fairy tales) olisi saanut alkunsa vasta renessanssin ja 
painokoneiden aikakaudella, 1500-luvulla. Kansansaduista tuttu juonikaava, jossa rutiköyhä protagonisti saa ensin haltuunsa ihmeelliset keinot ja sitten näitä käyttämällä kuninkaallisen puolison ja puoli valtakuntaa, on yhden ainoan miehen aikaansaannos eli Straparolan luomus. (Bottigheimer 2009, 93-95.)

Juonen prototyyppinä Bottigheimer pitää Saapasjalkakissaa. Sadun sankari, orvoksi jäänyt mökinpoika, saa perinnökseen vain kissan. Sujuvapuheinen kissa toteuttaa sarjan huijauksia, joiden seurauksena poika saa itselleen aatelisen identiteetin, kreivillisen linnan ja vaimokseen kuninkaan tyttären.

Bottigheimer tarkasteli lähemmin Saapasjalkakissan ja kahden muun sosiaalista nousua käsittelevän sadun lähteitä. Hän sulki pois - ilman perusteluja - sen mahdollisuuden, että Straparola olisi tukeutunut tuntemaansa folkloreen. Koska Bottigheimer ei löytänyt näille kertomusjuonille vastineita myöskään Straparolan hyödyntämästä tai tuntemasta kirjallisuudesta, hän päätyi siihen, että kirjailijan täytynyt keksiä satujemme suosituin juonikaava ihan itse. (Bottigheimer 2009, 91-92.)

Folkloristien närkästykseksi Bottigheimer esitti, että uutta juonikaavaa noudattavat sadut ovat voineet syntyä vain urbaanissa ympäristössä, ei siis maalaiskylissä ja talonpoikaisen väestön keskuudessa. Venetsian tapaisessa kaupungissa asui jo sivistyksen kanssa kosketuksiin joutunutta kansaa, esimerkiksi pikkukauppiaita, käsityöläisiä ja palvelijoita. (Bottigheimer 2009, 17-22, 113-115.)

Bottigheimer $(2009,106)$ hieroi vielä suolaa oralistien haavoihin väittämällä, että Euroopan väestön ehdoton enemmistö, maatalouden harjoittajat, eivät ole näytelleet pääosaa edes säätynousua kuvaavien satujen leviämisessä. Juonikaava olisi valloittanut Euroopan nimenomaan kääntäjien, kirjanpainajien ja kirjakauppiaiden avulla. Jo 1500-luvulla oli huomattu, että huokeilla painatteilla saattoi tehdä rahaa. Varhaismodernissa Euroopassa kirjoittajat, kääntäjät ja painokoneiden haltijat toivat markkinoille - sanan varsinaisessakin merkityksessä - sellaista viihdettä, joka sai vähävaraisetkin lukijat raottamaan kukkaroaan. (Bottigheimer 2009, 22.)

Bottigheimerin mukaan rahvas tyydytti satunälkäänsä myös jatkossa kirjallisin tekstein. 1600- ja 1700-luvulla näitä saatiin useiden satukirjailijoiden julkaisuista. Heistä tunnetuimpia olivat napolilainen Giambattista Basile (Il Pentamerone 1634-36) sekä ranskalaiset Marie-Catherine Le Jumel de Barneville (paronitar d'Aulnoy) ja Charles Perrault (Hanbiemon sadut 1697). (Bottigheimer 2009, 53-74.) Satujen kirjoittamisesta tuli 1700-luvulla muoti-ilmiö, ja painoista ilmestyi yhä uusia ranskankielisiä haltiatarsatuja. Näihin talkoisiin osallistuivat esimerkiksi Rousseau ja Katariina Suuri.

Se että 1900-luvulla eri maiden kansankerronnasta on löydetty noin 250 ihmesatujuonta (ks. ATU 2004), selittyy Bottigheimerin mielestä satukirjallisuuden antamista malleista. Kun Straparola oli luonut ryysyistä rikkauteen -juonen, kansa kehitti tästä omia muunnelmiaan ja saattoi sepittää aivan uusiakin kaavan mukaisia satuja.

Bottigheimerin teesit saivat osakseen kiukkuista kritiikkiä. Esimerkiksi Tartossa vuonna 2005 pidetyssä International Society for Folk Narrative Research' in kongressissa hänen esitelmästään keskusteltiin huutamalla. 
Satu Apo: Satugenre kirjallisuudentutkimuksen ja folkloristiikan riitamaana

\section{IMPERIUMIN VASTAISKU}

Folkloristien reaktio Bottigheimerin esittämiin väitteisiin oli jyrkkä torjunta. Vastustus huipentui vuoden 2010 lopulla julkaistuna Journal of American Folklore'n (= JAF) erikoisnumerona. Tässä Bottigheimerin kimppuun kävi kolme miestä, Jan Ziolkowski, Francisco Vaz da Silva sekä Dan Ben-Amos. Tässä joukossa Ben-Amos näyttää olevan ainoa päätoiminen folkloristi; Ziolkowski on keskiajan latinankielisen kirjallisuuden spesialisti, ja Vaz da Silva on antropologian ja folkloristiikan apulaisprofessori. Teemanumeron jälkipuolisko sisältää Bottigheimerin laajan vastauksen kriitikoilleen.

Suomesta katsellen Bottigheimeriin kohdistetun kritiikin jyrkkyys ja tyrmäysoperaation näyttävyys tuntuvat oudoilta: offensiiville oli omistettu Yhdysvaltojen arvostetuimman folkloristisen lehden kokonainen numero. Minusta Bottigheimerin väitteet ja argumentaatio olisi voitu vallan mainiosti kuitata JAF:n arvosteluosastoon sijoitetulla kritiikillä.

Mitä vastaväitteitä Bottigheimeria arvioinut trio esitti, ja miten se perusteli omat näkemyksensä? Kriitikot käyttivät kolmea strategiaa: empirian avulla kumoamista, vetoamista aiempiin tutkimuksiin sekä käsitteellistä ja teoreettista analyysia. Eniten he turvautuivat tekstien avulla todisteluun, eli he yksinkertaisesti etsivät ennen Straparolaa kirjoitettuja säätynousun kuvauksia, joissa on meille tuttua fantasiaa. Tällöin kriitikot kävivätjälleen kerran läpi antiikin ja keskiajan lähteitä. Saalis oli odotusten mukainen eli niukka. Jo 1900-luvun saduntutkijat tiesivät, että antiikin kirjallisuudesta ja keskiajalta löytyy runsaastikin oman kulttuurimme saduista tuttuja aihelmia eli motiiveja. Monitapahtumaiset ryysyistä rikkauteen -juonet ovat sen sijaan harvinaisia.

Bottigheimerin kritiikot löysivät kiistattomia säätynousu-satuja todella vähän; näitä kertyi tulkinnastani riippuen pari kolme kappaletta. Tulos itse asiassa vahvistaa Bottigheimerin väitettä siitä, että tämä juonikaava tai -tyyppi on lyönyt itsensä läpi vasta varhaismodernilla kaudella (1500-1790).

Dan Ben-Amos onnistui etsinnässään sekä kehnoimmin että parhaimmin. Hänen mukaansa keskiaikainen teologinen paraabeli neitoon rinnastetusta toora-käsikirjoituksesta, joka välillä päästää tiedonjanoisen miehen lähikontaktiin ja välillä taas vetäytyy tavoittamattomiin, olisi Neito tornissa-satu eli pitkälettisen Rapunzelin (ATU 310) vastine. (Ben-Amos 2010, 437-438). Toisaalta Bottigheimerkin joutui myöntämään, että Ben-Amosin esittelemä 1200-luvulta peräisin oleva kertomus äpäräpojasta, joka saa kuin saakin ylhäisen Joosuan tyttären puolisokseen, melkein täyttää säätynousu-sadun kriteerit. (Ben-Amos 2010, 438; Bottigheimer 2010, 472-474.)

Ziolkowski ja Vaz da Silva nojautuivat kritiikissään teoriaan eniten. Lukiessani heidän näkemyksiään minulle tuli tunne, että olin joutunut museoon. Ziolkowski ja Vaz da Silva tarjosivat käypänä saduntutkimuksena suomalaista menetelmää - josta kansainväliset tutkijat sanoutuivat irti jo 1920-1930-luvulla. (Vrt. Delarue 1957,31.) Maantieteellishistoriallisen metodin erityisenä ansiona Ziolkowski ja Vaz da Silva nostivat esiin satojen, jopa tuhansien toisintojen käyttämisen tutkimusaineistona. He eivät ottaneet selkeää kantaa siihen, että nämä toisintomeret on tallennettu vasta modernissa Euroopassa, 1800-1900-luvuilla.

Kriitikot pitävät suomalaisen koulukunnan tuottamaa satutyyppiluetteloa tieteelli- 
senä perusrakenteena (fulcrum), jonka avulla voidaan esimerkiksi arvioida yksittäisten satujuonten ikää. Niinpä Vaz da Silva $(2010,416)$ esittää, että Saapasjalkakissan täytyy olla ikivanha, koska se uusimman satutyyppiluettelon mukaan esiintyy jopa Siperiassa. Tämä sisältää sen epäkohteliaan oletuksen, että venäläiset, jotka lukivat kyseisen kertomuksen Perrault'n Hanbiemon saduista jo 1700-luvulla ranskaksi tai käännöksinä, eivät olisi pystyneet levittämään satua Siperiaan.

Toisena kovana sanana kriitikot esittelivät Vladimir Proppin funktiokaavan. Tämä taas kaadettiin sekä teorian että empirian avulla jo 1980-luvulla.(Vrt. Bremond \& Verrier 1982 ja Apo 1986, 160-162). Bottigheimer saa ivalliset moitteet siitä, ettei hän ole ottanut huomioon suomalaista menetelmää eikä Proppin saavutuksia. Hänen kriitikkonsa eivät kuitenkaan kerro, mitä hyötyä satujen historian tutkijalla on tällä hetkellä kummankaan tutkimussuuntauksen aikaansaannoksista. Oman kokemukseni mukaan suomalainen menetelmä ja Proppin strukturalismi eivät auta ratkomaan niitä kulttuuri- ja kirjahistoriallisia ongelmia, joiden kanssa saduntutkimus tällä hetkellä painii.

\section{MITÄ OPIMME JAF:N KESKUSTELUSTA?}

Metodologista viisautta sisältyi mielestäni eniten Jan Ziolkowskin kirjoitukseen. Hän muistutti, ettei tutkimuskohteen vanhimman käsikirjoitusversion löytäminen merkitse aina sitä, että teksti olisi kyseisen kertomuksen ensimmäinen ilmentymä. Meille säilyneen tekstin lähteenä tai innoittajana on voinut olla tuntematon määrä käsikirjoituksia, jotka ovat kadonneet. Käsikirjoitustekstin lähteenä on voinut olla myös suullinen kertomus, joka niin ikään on häipynyt historian hämärään.

Kaikki kriitikot tarjosivat saman selityksen sille, miksi ihmesatuja näkyy niin vähän antiikin ja keskiajan käsikirjoituksissa. He eivät usko tämäntapaisten kertomusten totaaliseen puuttumiseen vanhoista suullisista ja kirjallisista traditioista. Bottigheimer väittää näin - hänestä ihmesatujen näkymättömyys johtuu siitä, ettei niitä ollut ennen uutta aikaa olemassakaan. Kriitikot vetosivat vastaväitteissään runsaisiin tietoihin siitä, miten kielteisesti antiikin ja keskiajan auktorit ovat suhtautuneet rahvaan suullisiin ihmekertomuksiin eli "imettäjien juttuihin". Bottigheimer myöntää näiden viittausten olemassaolon, mutta muistuttaa, etteivät ne anna meille mitään tietoa torjuttujen kertomusten sisällöistä.

Pisimmän metodologisen miinuksen annoin kriitikoille siitä, että he sivuuttivat folkloren ikäämistä eniten vaikeuttavan tekijän: luotettavien aineistojen myöhäisyyden. Suhteellisen tarkkoja tietoja suullisesta kerronnasta alkoi kertyä vasta 1800-luvulla. Bottigheimer sen sijaan jaksoi muistuttaa tästä ainakin kymmenen kertaa.

Kaiken kaikkiaan Journal of American Folklore’ssa käyty vääntö jäi aika hedelmättömäksi eipäs-juupas -väittelyksi. Kiistely siitä, millaisia satutraditioita Euroopassa oli keskiajalla, leijuu ilmassa lähteiden niukkuuden vuoksi. Kaipasin kummaltakin osapuolelta epistemologista reflektiota eli sen pohtimista, riittävätkö eväämme ratkomaan näin etäisten vuosisatojen folkloreen liittyviä ongelmia.

Oma kantani Bottigheimerin teeseihin on sekä kriittinen että arvostava. En usko, että 
Satu Apo: Satugenre kirjallisuudentutkimuksen ja folkloristiikan riitamaana

ryysyistä rikkauteen -juonityyppi olisi Straparolan luomus. Kyseessä on tyhjä hypoteesi, jota ei voida osoittaa oikeaksi eikä vääräksi. En myöskään usko, että maalaisväestön osuus ihmesatulajin ylläpitäjänä ja kertomusten levittäjänä olisi niin olematon kuin Bottigheimer väittää.

Toisaalta pidän Bottigheimerin avaamaa keskustelua erittäin tärkeänä. Proosakerronnan lajien (satujen, tarinoiden) historiaa ei enää voida käsitellä ottamatta huomioon painetun kirjallisuuden vaikutusta. Folkloristien on syytä arvioida uudestaan koko tähänastinen saduntutkimus. Meidän on nöyrryttävä tutustumaan lukutaidon, painotuotteiden, lehdistön, kirjastojen, koulujen oppikirjojen ja kirjanlevityksen historiaan. (Vrt. Apo 2007, 29-30.) Kansankertomusten leviämistä selvitettäessä folkloristit tarvitsevat tietoja kääntämisen historiasta. Bottigheimerin jälkeen ei enää voida esittää yleistystä kansansatujen ikivanhuudesta eikä siitä, että ne ovat syntyneet viimeistään keskiaikana.

Miten selitämme perinteisellä ja uudella, Bottigheimerin viitoittamalla tavalla sen, että Suomesta on tavoitettu suullisia satuja, joilla on ilmiselvät vastineensa Straparolan Miellyttävissä öissä? Kansankertojamme näyttävät vieläpä rakastaneen näitä. SKS:n kansanrunousarkistosta löytyy Kissalan linnasta (ATU 545) yli 130 tallennetta. Toisesta hitistä, Laiskasta pojasta ja hauen sanoista (ATU 675) löytyy 168 muistiinpanoa. Kumpikin satu sijoittuu 15 eniten tallennetun suomalaisen ihmesadun joukkoon. (Apo 1986, 294.)

Ovatko suomalais-ugrilaiset esi-isämme saaneet nämä eteläiset kulttuurivaikutteensa jo ammoisina aikoina, joutuessaan kosketuksiin indoeurooppalaisten kansojen kanssa? Vai onko Suomesta käyty keskiajalla opissa tai pyhiinvaelluksilla alueilla, joilla kansa kertoi Straparolalle päätyneitä satuja? Olisiko maahamme saapunut, mahdollisesti Ruotsin kautta, sadunkertojia etelästä? Näistä leviämistavoista tuskin on kysymys. Epäilen vahvasti, että asialla ovat olleet kirjoittajat, kääntäjät, painokoneet ja kirjakauppiaat sekä viihdepitoinen lehdistö.

\section{FOLKLOREN JA KIRJALLISEN SATUTRADITION KIPUPISTE: GRIMMIN VELJEKSET}

Folkloren ja kirjallisten satujen välinen kipupiste ei sijoitu 1500-luvulle vaan 1800-luvun alkuun, tarkemmin sanoen Jacob Grimmin ja Wilhelm Grimmin toimintaan kansansatujen julkaisijoina ja esittelijöinä. Heidän Kinder-und Hausmärchen -kokoelmansa on saksankielisen kirjallisuuden eniten käännetty teos. Se alkoi valloittaa Eurooppaa jo 1830-luvulla. Grimmin sadut vaikuttivat suulliseen sadunkerrontaan useissa maissa, myös Skandinaviassa ja Suomessa. Grimmien esimerkki käynnisti 1830- ja 1840-luvulla kansansatujen keruun ja julkaisemisen myös saksalaisen kielialueen ulkopuolella. Veljesten vaikutus kansanrunoudentutkimukseen on todella merkittävä, myös ja etenkin Suomessa.

Grimmien satukokoelma sisältää monia satulajeja, ihmesatujen lisäksi esillä ovat eläinsadut, novellit, pilasadut ja legendat. Ihmesatuja sisältyy Kinder-und Hausmärchen -kokoelmaan noin sata.

Wilhelm ja Jacob Grimm antavat tietoja kokoelmansa synnystä esipuheissaan ja yksit- 
täisiin satuihin liitetyissä kommentaareissa. Tapa, jolla veljekset esittelevät aineistonsa keruuta ja käyttämiään informantteja, on osoitettu harhaanjohtavaksi. Bottigheimerin teos Fairy Tales: A New History sisältää katsauksen uusimman Grimm-tutkimuksen tuloksiin. (Ks. myös Martus 2010, 208-211; 216-217). Merkittävä osa Grimmin saduista ei ole lähtöisin saksalaisen kansan suusta eikä sen syvistä riveistä; Grimmien tärkeimmäksi kentäksi on osoittautunut kirjasto. He hyödynsivät latinan-, saksan-, ranskan- ja italiankielisiä kertomusmateriaaleja, joiden aikahaarukka ulottuu keskiajalta veljesten oman ajan kirjallisuuteen ja lehtiin. Tämän lisäksi kansanperinteen harrastajat lähettivät veljeksille löytämiään tai tallentamiaan satuja.

Grimmien käyttämistä suullisista informanteista suurin osa oli lukutaitoisia ja lukuhaluisia. Niinpä he kertoivat veljeksille kirjoista lukemiaan satuja. Mukaan mahtui esimerkkejä myös kuulemalla opituista kertomuksista. Melkoinen osa tiedonantajista oli ranskaa taitavia hugenotteja. Ehdoton enemmistö kertojista ja avustavista kerääjistä kuului porvaristoon tai pikkuporvaristoon. Jopa veljesten tähti-informantti, talonpoikaisvaimoksi esitelty Dorothea Viehmann, oli kyläräätälin leski, ranskalaissukuisen majatalonomistajan tytär ja lukutaitoinen henkilö.

Grimm-tutkimuksen Grand Old Manin, Heinz Rölleken mukaan veljesten 210 satutekstistä noin kolmannes pohjautuu selvästi yhteen ainoaan kirjalliseen tekstiin. (Rölleke 1998, 589-591.) Toisena työstämistapanaan Grimmit käyttivät useiden kirjallisten lähteiden yhdistelyä. Lumikki on todennäköisesti syntynyt näin. ${ }^{5}$ Useista lähteistä koostettujen tekstien määrää on tässä vaiheessa vaikea arvioida. Voi olla, että kirjallisuuteen pohjautuvien kertomusten määrä kohoaa lähelle sataa, ehkä ylikin. Koska Grimmien vaikutus kansansatujen keruuseen, julkaisemiseen ja tutkimiseen oli niin voimakas, heidän kokoelmansa kirjallisuuspitoisuus ei ole enää pikkujuttu.

1830-luvulta lähtien Kinder-und Hausmärchen ja sen esipuheet muokkasivat kautta Euroopan käsityksiä siitä, millainen on aito ja hyvä kansansatu. Mitä vanhemmiksi veljekset elivät, sitä enemmän saksalaiset perinteenkerääjät lähettivät heille grimmiläisiä tekstejä. (Martus 2010, 478.) Syy oli osaksi kerääjien, jotka muokkasivat tallenteitaan Grimmin satujen mukaisiksi, ja osaksi sadunkertojien, jotka olivat ottaneet veljesten sadut nopeasti omikseen. Wilhelm Grimm oli kehittänyt iskevän satutyylinsä suullisen kerronnan inspiroimana. Juoneltaan selkeät, suhteellisen lyhyet sekä yksinkertaisin lausein ja virkkein etenevät sadut kestivät kääntämisen hyvin. Niitä oli myös helppo lukea ääneen. Niinpä veljesten sadut levisivät vaivattomasti suulliseen kerrontaan useissa maissa, esimerkiksi Tanskassa, Ruotsissa ja Suomessa.

Suomessa Grimmien satuja alettiin levittää kansalle jo 1840-luvulla. Aluksi vuorossa olivat halvat arkkisadut (Satu Hannusta ja Rietusta, Rikkaasta miehestä ja köyhästä miehestä, Kolme kehroa [kehrääjää], Kaksitoista veljestä). (Brummer-Korvenkontio 2000, 577.) Ensimmäinen suomennoskokoelma, Kaksitoista kummallista satua, ilmestyi jo 1849. Laaja, 50 tekstiä käsittävä kokoelma julkaistiin 1876. Kaikki edellä mainitut painotuotteet ehtivät vaikuttaa 1800-luvun suuriin kansansatukeruisiin. (Apo 1986, 58-63.) 
Satu Apo: Satugenre kirjallisuudentutkimuksen ja folkloristiikan riitamaana

\section{KANSAN VAI KIRJALLISTEN SATUJEN TYYPPILUETTELO?}

Kysymys Grimmien kokoelman kansanomaisuudesta saattaa uuteen valoon suomalaisen folkloristiikan kruununjalokiven eli Antti Aarneen kansainvälisen satutyyppiluettelon vuodelta 1910. Luettelosta ilmestyi uusin laitos vuonna 2004 saksalaisen kirjallisuudentutkijan Hans-Jörg Utherin toimittamana.

Aarne rakensi kansainvälisten satujen tyyppiluettelonsa kolmen tekstikorpuksen pohjalta. Näistä kaksi edustaa arkistojen aarteita. Tallenteet ovat peräisin Tanskasta ja Suomesta lähialueineen. Iältään nämä kansansatuaineistot ovat nuoria. Svend Grundtvigin keräämät tanskalaiset tallenteet ovat peräisin 1840-1850-luvuilta. (Vrt. Swahn 1993, 242-243.) Suurin osa suomalaisista kansansaduista on merkitty muistiin vasta 1880-1890-luvuilla. Koska Aarnen käyttämät arkistoaineistot olivat näin myöhäisiä, Grimmien sadut olivat ehtineet vaikuttaa sekä tanskalaisiin että suomalaisiin kertojiin jo usean vuosikymmenen ajan.

Kirjallisten satujen osuus tyyppiluettelon rakentamisessa kohosi toiseen potenssiin, kun Aarne valitsi kolmanneksi korpuksekseen Grimmien kokoelman. Aarne piti tätä tieteellisenä ja puhtaasti folkloristisena aineistokokoelmana. ${ }^{6}$

Valinnan seurauksena Aarne joutui määrittelemään kansansaduiksi juonia, joilla oli vaihtelevan mittainen historia kaunokirjallisina konstruktioina. Aarne sertifioi tyyppinumerollaan kansansaduksi esimerkiksi Kaunottaren ja hirviön (Aa 425C), jonka tekijät, Gabrielle-Suzanne de Villeneuve ja Jeanne Leprince de Beaumont, tunnetaan tarkkaan. (Lemirre 2000,772.) Kansansaduksi muuntui myös lastenkirjailija Karoline Stahlin luomus Lumivalko ja Ruusunpuna (= Aa 426). (Rölleke 1998, 272-285; Uther 2008,333.)

Tilanteen tekee ironiseksi se, että suomalainen maantieteellis-historiallinen koulukunta suhtautui kirjallisiin satuihin äärimmäisen torjuvasti. Aarne julkaisi 1913 kansainväliselle tiedeyhteisölle tarkoitetun metodioppaan nimeltään Leitfaden dervergleichenden Märchenforschung. Siinä vaaditaan, että satujen tutkijan on hankittava mahdollisimman täydellinen aineisto. Tutkijan on myös harjoitettava tiukkaa lähdekritiikkiä. Tutkimusaineistosta piti poistaa kaikki tekstit, joilla oli edes välillinen yhteys kirjallisiin satuihin. Aarne antoi vakavan varoituksen: "Jos tutkija ei tällaisessa tapauksessa pidä varaansa, hän harhautuu tekemään vääriä johtopäätöksiä." (Aarne 1913, 63.)

Kirjallisuuteen pohjaavan aineiston torjuminen koski myös Kansanrunousarkistoon saapuneita satutekstejä. Kokoelmiin sai ottaa vain puhtaita, painetun sanan saastuttamattomia tallenteita. Myöhempien arkistointiohjeiden mukaan myös omaperäiset sepitteet piti siivota pois ja sijoittaa kaikki epäkelvot tekstit f-kokoelmaan. Kertojien rakastamat Grimmin sadut läpäisivät kuitenkin arkiston suodattimet kevyesti. (Apo 1986, 62.)

Kinder-und Hausmärchen' in sisällyttäminen tyyppiluettelon pohja-aineistoon saattoi olla siunauksellista uuden historiaparadigman kannalta. Aarnen valinnasta johtuen tyyppiluettelo kattaa tärkeimmät klassikkosadut, joita on kerrottu sekä kirjallisesti että suullisesti. Uther on vahvistanut satutyyppiluettelon litterääriä puolta lisäämällä satujen esittelyyn tietoja niiden kirjallisesta historiasta. Ainoa haitta on, että hakuteoksen nykyinen nimi, The Types of International Folktales, viittaa vain folkloreen. Kirjallisuudentutkijat - esimerkiksi Bottigheimer - eivät mielellään käytä aarnelaisia tyyppikoodeja. 
Satu Apo: Satugenre kirjallisuudentutkimuksen ja folkloristiikan riitamaana

\section{KANSA JA TUTKIJAT KIRJALLISUUDEN PYÖRTEISSÄ}

Mikä on kansan rooli tässä kirjallistuneessa satukuviossa? Minusta varsin kunniallinen. Kansankertojat eivät ole olleet eurooppalaisen massaviihteen kömpelöitä toistajia vaan luovia uudelleen kertojia sekä täysin uusien satujen sepittäjiä. On myös mahdollista, että osa kansansaduista on peräisin ajalta ennen Gutenbergia. Suomalaisen menetelmän haaksirikko 1920-1930-luvulla tosin osoitti, että näin vanhojen satujen jäljittäminen on erittäin hankalaa. Oli niin tai näin, kansankertojat tekivät saduistaan sellaisia, että ne vastasivat heidän elämismaailmaansa ja heidän tuntemiaan genrekonventioita. $\mathrm{He}$ toimivat täsmälleen samoin kuin vanhojen satujen kirjalliset versioijat.

Muuttuuko satujen tulkinta uuden historiaparadigman myötä? Todennäköisesti, mielestäni parempaan suuntaan. Syvähenkisimmiltä spekulaatioilta putoaa pohja, kun sadut ankkuroidaan varhaismoderniin ja moderniin Eurooppaan. Tällöin ei tunnu järkevältä etsiä ihmesatujen historiallisia juuria muinaisista uskonnoista tai kulttuureista. Myös psykoanalyytikkojen horinat satujen ikuisista viisauksista tuntuvat entistä kummallisemmilta.

Suomalaisuuden historian kannalta kyseessä on hauska käänne. Kansansadutkin osoittavat, että kulttuurimme on ollut jo autonomian ajalla tiiviissä yhteydessä läntiseen Eurooppaan ja sen nousevaan mahtiin eli Saksaan, silloiseen Preussiin ja pikkuvaltioihin. Jos siirrymme aikakoneella 1840-luvulle, silmiemme eteen avautuu kaunis näky: samaan aikaan kun J.V. Snellman lukee työhuoneessaan Hegeliä, kansamme syvät rivit kertovat väentuvissa toisilleen Grimmin satuja.

\section{VIITTEET}

1 ATU = The Types of International Folktales, toim. Hans-Jörg Uther 2004, FFC 284.

2 Cupidon ja Psychen tarina sisältyy Apuleiuksen humoristiseen pikareskiromaaniin Kultainen aasi (Asinus aurea $=$ Metamorphoseon libri). Teos on ainoa kokonaisena säilynyt roomalainen romaani.

3 "Erant in quadam civitate rex et regina. Hi tres numero filias forma conspicuas habuere..... Apuleio 1996, 264.

4 Meille tutun Ruususen paralleeli (ristiäisjuhlat, kehrääminen, uni, prinssin aiheuttama raskaus, vauva imaisee pellavatikun äitinsä sormesta, prinsessa herä) sisältyy episodina 1300-luvulla kirjoitettuun Perceforest-romanssiin. Ranskankielinen teksti on proosaa. Ks. Apo 2004, 141-142.

5 Grimmien Sneewittchen pohjautuu tärkeimmiltä osiltaan Johann Karl August Musäuksen (1735-1787) satuun Richilde. Se sisältyy Musäuksen suureen kertomuskokoelmaan Volksmärchen der Deutschen (1782/86; ks. 1987, 111-148). Grimmit saivat Lumikin aihelmia myös Albert Ludwig Grimmin satunäytelmästä Schneewittchen; tämä sisältyy A.L. Grimmin kokoelmaan Kindermährchen (1809). Ks. Uther 2008, 125-126, 128.

6 Aarne kirjoitti $1914(21-22)$ seuraavasti: "Die grimmischen Märchen stammen zum 
Satu Apo: Satugenre kirjallisuudentutkimuksen ja folkloristiikan riitamaana

grössten Teil aus mündlicher Überlieferung, ... Aber die von Brüdern Grimm in den Märchen vorgenommenen Veränderungen machen die Sammlung doch nicht für wissenschaftliche Zwecke unbrauchbar."

\section{KIRJALLISUUS}

AARNE, ANTTI 1910: Verzeichnis der Märchentypen. FF Communications 3. Helsinki: Suomalainen tiedeakatemia.

AARNE, ANTTI 1913: Leitfaden der vergleichenden Märchenforschung. FF Communications 13. Helsinki: Suomalainen tiedeakatemia.

AARNE, ANTTI 1914: Übersicht der Märchenliteratur. FF Communications 14. Helsinki: Suomalainen tiedeakatemia.

APO, SATU 1986: Ihmesadun rakenne. Juonien tyypit, pä̈jaksot ja henkilöasetelmat satakuntalaisessa kansansatuaineistossa. Helsinki: SKS.

APO, SATU 2004: Topeliuksen Ruususen eurooppalaiset juuret. Apo, Satu \& Norrback, Märtha (toim.), Topelius elää - Topelius lever. Jyväskylä: Atena.

APO, SATU 2007: The Relationship between Oral and Literary Tradition as a Challenge in Fairy-Tale Research: The Case of Finnish Folktales. - Marvels \& Tales 21(1).

APO, SATU 2011: Tuhkimon kenkä. - Nieminen, Aili et al (toim.), Aineen taikaa. Näkyvän ja näkymättömän kulttuurin jäljillä. Helsinki: SKS.

APULEIUS = APULEIO 1996: Le metamorfosi o L'asino d'oro. Milano: Biblioteca Universale Rizzoli.

ATU = Uther, Hans-Jörg (ed.), The Types of International Folktales. FF Communications 284. Helsinki: Academia Scientiarum Fennica.

BEN-AMOS, DAN 2010: Introduction: The European Fairy-Tale Tradition between Orality and Literacy; Straparola: The Revolution That Was Not. - Journal of American Folklore 123(490).

BOTTIGHEIMER, RUTH B. 2002: Fairy Godfather: Straparola, Venice, and the Fairy Tale Tradition. Philadelphia: University of Pennsylvania Press.

BOTTIGHEIMER, RUTH B. 2009: Fairy Tales: A New History. Albany \& New York: Excelsior Editions.

BOTTIGHEIMER, RUTH B. 2010: Fairy Godfather, Fairy-Tale History, and FairyTale Scholarship: A Response to Dan Ben-Amos, Jan M. Ziolkowski, and Francisco Vaz da Silva. Journal of American Folklore 123(490).

BREMOND, CLAUDE \& VERRIER, JEAN 1982: Afanassiev et Propp. Littérature vol. 45, 1982.

BRUMMER-KORVENKONTIO, MARKUS 2000: Lapsuuden kirjat Suomessa 1799-1899. Helsinki: C. Hagelstamin antikvaarinen kirjakauppa \& Helsingin yliopiston kirjasto.

DELARUE, PAUL 1957: Le conte populaire francais. I . Paris: Éditions Érasme.

GRANDET, PIERRE 1998: Contes de l'Egypte ancienne. Paris: Hachette Littératures. GRIMM, BRÜDER 2003: Kinder- und Hausmärchen. Düsseldorf: Albatros Verlag. 
Satu Apo: Satugenre kirjallisuudentutkimuksen ja folkloristiikan riitamaana

[1857]

HEIKKILÄ, TUOMAS (toim.) 2010: Kirjallinen kulttuuri keskiajan Suomessa. Helsinki: SKS.

LAINE, TUIJA 2012. Kirkon ja kansanopetuksen kirjat Suomessa uuden ajan alussa. - Laine, Tuija (toim.), Luther, reformaatio ja kirja. Helsinki: Suomen kirkkohistoriallinen seura.

LEMIRRE, ELISABETH 2000: Le cabinet des fées. Arles: Éditions Philippe Picquier.

MARTUS, STEFFEN 2010: Die Brüder Grimm. Eine Biographie. Berlin: Rowohlt.

MOSER-RATH, ELFRIEDE 1977: Ammenmärchen. Enzyklopädie des Märchens. Band 1. Berlin \& New York: Walter de Gruyter.

MUSÄUS, JOHANN KARL AUGUST 1987: Volksmärchen der Deutschen. Berlin: Verlag Neues Leben. [1782/86]

RAUSMAA, PIRKKO-LIISA (toim.)1988: Suomalaiset kansansadut. 1. Ihmesadut. Helsinki: SKS.

RUBINI, LUISA 2007: Straparola, Giovan Francesco. Enzyklopädie des Märchens. Band 12. Berlin \& New York: Walter de Gruyter.

RÖLLEKE, HEINZ 1998: Grimms Märchen und ibre Quellen. Die literarischen Vorlagen der Grimmschen Märchen synoptisch vorgestellt und kommentiert. Trier: Wissenschaftliche Verlag Trier.

STRAPAROLA, GIOVAN FRANCESCO 1894: The Nights of Straparola. Translated by W.G. Waters. London: Lawrence and Bullen. [1550/53]

SWAHN, JAN-ÖJVIND 1993: Märchenforschung in Skandinavien. - Röth, Diether \& Kahn, Walter (Hrsg.), Märchen und Märchenforschung in Europa. Ein Handbuch. Frankfurt am Main: Haag \& Herchen.

TING, NAI-TUNG 1974: The Cinderella Cycle in China and Indo-China. FF Communications 213. Helsinki: Suomalainen Tiedeakatemia.

UTHER, Hans-Jörg 2008: Handbuch zu den "Kinder- und Hausmärchen" der Brüder Grimm. Berlin \& New York: Walter de Gruyter.

VAZ DA SILVA, FRANCISCO 2010: The Invention of Fairy Tales. Journal of American Folklore 123(490).

ZIOLKOWSKI, JAN M. 2010: Straparola and the Fairy Tale: Between Literary and Oral Tradition. Journal of American Folklore 123(490).

ZIPES, JACK 1979: Breaking the Magic Spell: Radical Theories of Folk \& Fairy Tales. London: Heinemann.

Satu Apo on folkloristiikan emeritaprofessori Helsingin yliopistossa. 